\title{
The wise provisioning of social media among the young people of Tanjung anom Village, Deli Serdang
}

\author{
Munzaimah Masril ${ }^{1 *}$, Yovita Sabarina Sitepu ${ }^{1}$, \\ ${ }^{1}$ Faculty of Social Sciences and Political Sciences, Universitas Sumatera Utara \\ *Email: munzaimah.m@usu.ac.id
}

\begin{abstract}
The intensity of social media consumption for young people is now very high, due to the rapid flow of information circulating directly proportional with to the ease of access the social media itself. But there are still some young people who have not equipped themselves with the ability to recognize the benefits and also the dangers of social media consumption itself. The results of observations through the community partner show that the young people in Tanjung Anom district tend to assume information obtained through social media is information from trusted sources. The lack ability of the young people to recognize the benefits and impacts of social media consumption is due to the fact that they rarely get socialization or education about the impact of social media consumption from the government or non-government organizations that may concern about it. This phenomenon certainly needs attention because the information flow circulates very quickly and easily through the various social media platform, it would be very dangerous if these young people then become one of the parties who carry on the information obtained without filtering first. These community service activities carried out at the young people community in Tanjung Anom district discussing about the social media platforms, the ethics in social media consumption, and also sharing about various problems may occur when accessing information on social media. This activity is expected to initiate small changes related to the ability of social media literacy for young people in the Tanjung Anom district.
\end{abstract}

Keyword: Social media, competency, young people

\begin{abstract}
Abstrak
Intensitas konsumsi media sosial untuk kaum muda sekarang sangat tinggi, karena arus informasi yang cepat beredar berbanding lurus dengan kemudahan mengakses media sosial itu sendiri. Namun masih ada beberapa anak muda yang belum membekali diri dengan kemampuan mengenali manfaat dan juga bahaya konsumsi media sosial itu sendiri. Hasil pengamatan melalui mitra masyarakat menunjukkan bahwa anak muda di Kabupaten Tanjung Anom cenderung menganggap informasi yang diperoleh melalui media sosial adalah informasi dari sumber terpercaya. Kurangnya kemampuan anak muda untuk mengenali manfaat dan dampak dari konsumsi media sosial disebabkan oleh kenyataan bahwa mereka jarang mendapatkan sosialisasi atau pendidikan tentang dampak konsumsi media sosial dari pemerintah atau organisasi non-pemerintah yang mungkin mengkhawatirkannya. Fenomena ini tentunya perlu mendapat perhatian karena arus informasi yang beredar sangat cepat dan mudah melalui berbagai platform media sosial, akan sangat berbahaya jika anak-anak muda ini kemudian menjadi salah satu pihak yang meneruskan informasi yang diperoleh tanpa filter terlebih dahulu. Kegiatan pengabdian masyarakat ini dilakukan di komunitas anak muda di Kabupaten Tanjung Anom yang membahas tentang platform media sosial, etika dalam konsumsi media sosial, dan juga berbagi tentang berbagai masalah yang mungkin terjadi ketika mengakses informasi di media sosial. Kegiatan ini diharapkan dapat memulai perubahan kecil terkait dengan kemampuan literasi media sosial untuk kaum muda di Kabupaten Tanjung Anom.
\end{abstract}

Kata Kunci: Media sosial, kompetensi, anak muda 


\section{PENDAHULUAN}

Akses media telah menjadi kebutuhan salah satu kebutuhan primer dari setiap orang. Itu dikarenakan adanya kebutuhan akan informasi, hiburan, pendidikan dan akses pengetahuan dari belahan bumi yang berbeda. Kemajuan teknologi dan informasi serta semakin canggihnya perangkat-perangkat yang diproduksi oleh industri seperti menghadirkan dunia dalam genggaman. Istilah ini sejajar dengan apa yang diutarakan oleh Thomas Friedman (2007) sebagai the world is flat bahwa dunia semakin rata dan setiap orang bisa mengakses apa pun dari sumber mana pun. Selain itu juga sebagaimana diulas Richard Hunter (2002) dengan kehadiran media baru (new media) menjadikan informasi sebagai sesuatu yang mudah dicari dan terbuka. Media tradisional seolah-olah mendapatkan pesaing baru dalam mendistribusikan berita (Davison, 2012).

Jika selama ini institusi media sebagai lembaga yang mendominasi pemberitaan, kehadiran internet dan media sosial memberikan keleluasaan bagi khalayak untuk ikut dalam berkompetisi menyebarkan informasi atau peristiwa yang terjadi disekitar mereka. Institusi media bisa saja menyembunyikan peristiwa, namun sebaliknya melalui internet khalayak mendapatkan peristiwa tersebut dari khalayak lainnya (Nasrullah, 2017).

Gambar 1 menunjukkan data saat ini terkait populasi masyarakat Indonesia yang menggunakan telepon genggam ataupun telepon pintar sudah di atas $50 \%$, di mana melalui kedua perangkat tersebut sangat mudah untuk mengakses informasi. Artinya kehadiran media sosial menjadi sangat fenomenal, dimana saat ini Facebook, Twitter, Instagram, hingga Whatsapp menarik minat banyak orang.

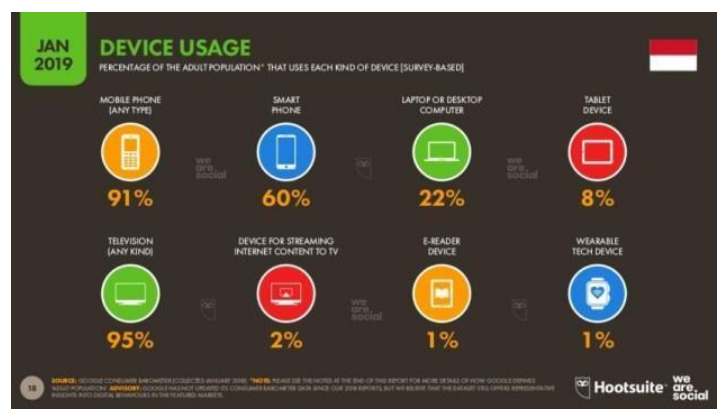

Gambar 1. Info Grafis tentang penggunaan media dalam mengakses informasi (wearesocial.com)

Saat ini sangat mudah seseorang untuk memperoleh informasi dari berbagai jenis platform media sosial. Beberapa media sosial yang tersaji pada info grafis gambar 2 tersebut, kemudian tidak hanya digunakan untuk mendistribusikan informasi yang bisa dikreasikan oleh pemilik akun (user) itu sendiri, tetapi juga memiliki dasar sebagai portal untuk membuat jaringan pertemanan secara virtual dan medium untuk berbagi informasi (Gilardi, 2009).

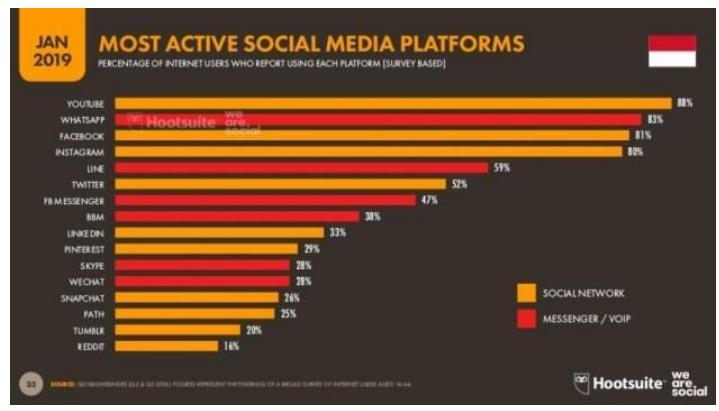

Gambar 2. Info Grafis tentang platform media sosial yang banyak diakses (wearesocial.com) 
Berdasarkan informasi dalam bentuk grafis pada gambar 3 dapat dilihat bahwa orang Indonesia cenderung menghabiskan waktunya untuk mengakses internet dengan mengakses media sosial ataupun berkirim pesan singkat. Selain itu juga sebaran pengguna media sosial berdasarkan usia dan jenis kelamin di dominasi oleh penduduk usia muda dengan rentang usia 18 - 34 tahun berjenis kelamin laki-laki.

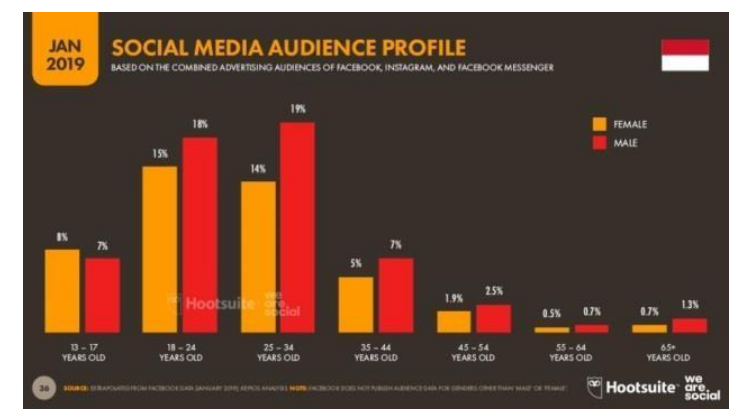

Gambar 3. Info grafis pengguna media sosial berdasarkan usia dan jenis kelamin (wearesocial.com)

Waktu yang digunakan oleh mayoritas penduduk Indonesia untuk mengakses internet dalam satu hari sekitar 8 jam 36 menit, sedangkan untuk mengakses media sosial sekitar 3 jam 26 menit berdasarkan survey yang dilakukan per Januari 2019 (www.wearesocial.com)

Merujuk pada data yang dirilis Asosiasi Pengguna dan Perilaku Internet (APJI) tahun 2018 yang menyebutkan jumlah pengguna internet di Indonesia saat ini adalah 143,26 juta atau setara dengan 54,68\% jumlah penduduk Indonesia yang jumlahnya 262 juta orang. Dimana untuk Sumatera Utara pengguna internetnya adalah 3,5 juta orang dengan sebaran terbanyak ada di Kota Medan yaitu 994.000 orang dan Kabupaten Deli Serdang sebesar 670.000 pengguna.

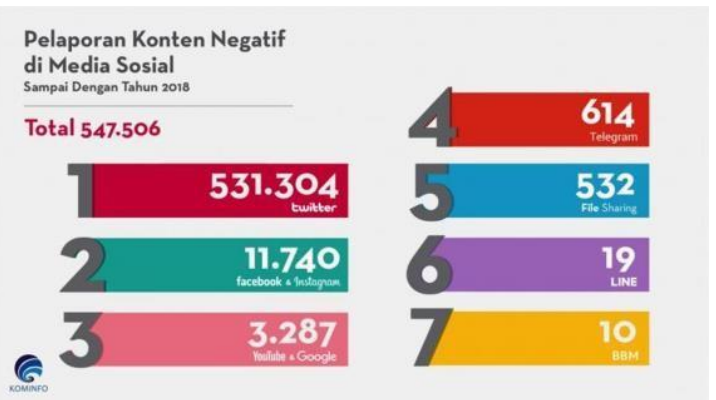

Gambar 4. Info grafis pelaporan konten negatif (Kominfo, 2019)

Besarnya angka pengguna internet ini tentu menjadi potensi sekaligus tantangan bagi masyarakat Kabupaten Deli Serdang. Potensinya tentu berkaitan dengan pertumbuhan bisnis pasar industri digital yang berkontribusi besar untuk ekonomi Kabupaten Deli Serdang menjadi pusat pertumbuhan untuk Sumatera Utara. Lebih lanjut, di era sekarang konektivitas internet menjadi syarat bagi pertumbuhan ekonomi sebuah negara. Namun, tantangannya juga demikian, apalagi dengan marak beredarnya berita-berita palsu (hoax) di masyarakat (Davidson, 2012).

Hal ini pula yang harus disikapi di Kelurahan Tanjung Anom, kecamatan Pancur Batu, Deli Serdang. Perkembangan intenet di Kelurahan Tanjung Anom cukup pesat yang hal ini disebabkan jarak antara wilayah ini dengan Kota Medan sangat dekat dan berbatasan langsung secara teritorial.

Luas wilayah Kelurahan Tanjung Anom adalah 5.260 ha yang juga merupakan salah stau 
wilayah terbesar di Kecamatan Pancur Batu. Dimana jumlah penduduk Kelurahan Tanjung Anom adalah laki-laki sebanyak 5.663 jiwa dan perempuan sebanyak 5.505 jiwa dengan jumlah keseluruhan adalah11.168 jiwa. Kemudian untuk anak-anak muda di Kelurahan Tanjung Anom yang umurnya 15-39 tahun adalah 4.847 jiwa.

Lebih lanjut jarak antara Universitas Sumatera Utara (Medan) dengan Keluarahan Tanjung Anom $11 \mathrm{Km}$ yang dapat ditempuh dengan lama perjalanan 29 menit.

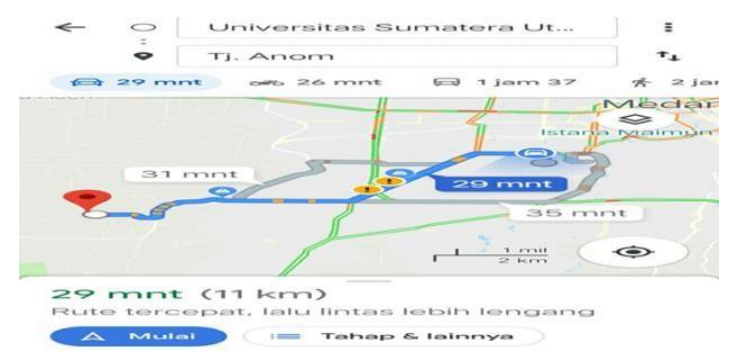

Gambar 5. Peta Jalan Menuju Kelurahan Tanjung Anom, Kecamatan Pancur Batu, Kabupaten Deli Serdang

Sejak era digitalisasi masuk ke Kelurahan Tanjung Anom, Rata-rata penduduk anak- anak muda yang umurnya 15-39 tahun tersebut aktif menggunakan media sosial Facebook, Instagram, path dan Twitter untuk mengakses informasi mengenai ekonomi, sosial, gaya hidup hingga politik. Hal ini disebabkan di samping akses internet lebih mudah, murah dan efisien kecenderungan masyarakat Kelurahan Tanjung Anom memperoleh informasi aktual dari koran terbatas dan jika harus memperoleh informasi yang tersaji dari radio atau televisi yang umumnya masyarakat urban lainnya memiliki keterbatasan waktu karena harus bekerja. Belum lagi penduduk Kelurahan Tanjung Anom yang sedang duduk dibangku Sekolah Menengah Atas rata-rata sudah menggunakan telepon seluler (gadget). Lebih lagi, rata-rata masyarakat, anak-anak remaja dan dewasa Kelurahan Kelurahan Tanjung Anom menempuh pendidikan tinggi di Kelurahan Tanjung Anom banyak melakukan aktifitas di daerah mereka.

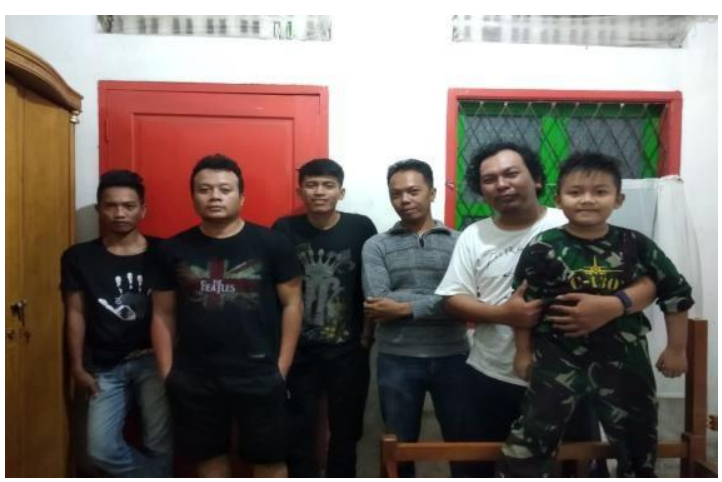

Gambar 6. Beberapa anggota Komunitas Milenial Bijak

Namun, Intensitas penggunaan media sosial internet oleh Masyarakat Kelurahan Tanjung Anom tidak disertai oleh pendidikan mengenai kelebihan dan bahaya penggunaan media sosial. Hal ini disebabkan sangat minimnya pengetahuan mereka tentang dampak bila salah menggunakan media sosial. Penyebabnya anak-anak muda Kelurahan Tanjung Anom jarang mendapatkan sosialisasi mengenai penggunaan media sosial oleh berbagai institusi, lembaga dan pelatihan seperti yang banyak dilakukan secara swadaya atau dilakukan lembaga pemerintah. Padahal ketertarikan para pengguna media sosial di Kelurahan Tanjung Anom yang kebanyakan menggunakan Facebook kerap menghampiri lini masa beranda Facebook 
dengan berbagai pendapat yang terkadang belum tentu benar dan menyesatkan. Fenomena ini tentu sangat berbahaya jika salah menyampaikan informasi atau melanggar privasi orang lain bisa terkena pidana.

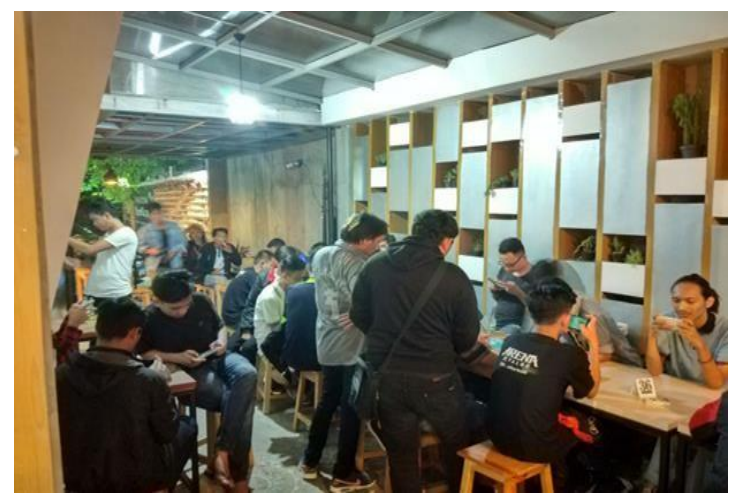

Gambar 7. Gambaran aktivitas kelompok Mitra di Kelurahan Tanjung Anom

Hal ini terdapat di dalam Undang- Undang Republik Indonesia Nomor 19 Tahun 2016 sebagai Perubahan Atas Undang- Undang Nomor 11 Tahun 2008 Tentang Informasi dan Transaksi Elektronik (UU ITE) yang dalam salah satu bagian di pasal 26 ayat 1 Setiap Orang yang dilanggar haknya sebagaimana dapat mengajukan gugatan atas kerugian yang ditimbulkan. Belum lagi bila salah membagikan konten pemberitaan yang berhubungan dengan tindakan asusila (pornografi), penghinaan, penistaan agama/suku/ras atau perbuatan tidak menyenangkan bisa dikenakan pidana penjara dan denda yang disesuaikan hasil putusan pengadilan.

Terbukti secara empirik beberapa kasus pidana di berbagai wilayah di Indonesia utamanya wilayah provinsi Sumatera Utara yang diakibatkan kesalahan penggunaan media sosial, di mana mayoritas terkait konten politik dan pornografi.

Dewasa ini hubungan media sosial dan dunia nyata hampir tidak bisa dipisahkan lagi dalam proses aktivitas. Sebab, pada era digital hampir semua aktivitas masyarakat dilakukan di dunia maya. Baik itu yang berkaitan dengan kegiatan politik, kegiatan ekonomi hingga menyikapi kebijakan pemerintah dari pusat ke daerah informasinya dapat secara cepat diakses dan ketahui. Secara empiris, pendidikan bijak media sosial oleh lembaga pemerintah melalui kementerian Komunikasi dan Informatika Republik Indonesia (Kominfo RI), Departemen hingga lembaga kedinasan mengenai penggunaan sudah mulai marak disosialisasikan di wilayah-wilayah di Indonesia. Meski belum secara keseluruhan hanya dilakukan di wilayahwilayah perkotaan saja dan belum dilaksanakan sampai tingkat kelurahan.

Pengabdian masyarakat dalam wujud pendidikan bijak media sosial di era digital ini diharapkan mampu memberikan pengetahuan tentang dampak baik dan buruk penggunaan media sosial. Kelompok mitra juga memiliki pemahaman yang kuat tentang digitalisasi, komunikasi massa, internet dan potensinya dalam proses kehidupan bermasyarakat.

Pendidikan bijak media sosial ini dalam skala yang luas juga menjadi bagian yang penting utamanya terkait Indonesia akan memperoleh bonus demografi tahun 2025- 2035. Dimana menurut prediksi Badan Pusat Statistik (BPS), jumlah penduduk Indonesia saat itu adalah 305,6 juta jiwa dengan persentase angkatan kerja produktif mencapai $66,6 \%$.

Kategori angkatan kerja produktif yang dimaksud BPS adalah orang-orang yang umurnya 15-64 tahun, sementara angkatan kerja tidak produktif umur 0-14 tahun dan umur di atas 65 tahun. Tentu kita tentu tidak ingin bahwa bonus demografi kita akan di isi oleh generasi hoax. Bayangkan pula apa jadinya Indonesia di tahun tersebut jika saat ini saja pergerakan dunia digital semakin tidak terkendalikan.

Adapun target dari pengabdian masyarakat dalam wujud Pendidikan Bijak Media Sosial di Kelurahan Tanjung Anom, Kecamatan Pancur Batu, Kabupaten Deli Serdang adalah 
Kelompok mitra Komunitas Milenial Bijak. Melalui kegiatan ini diharapkan Kelompok mitra lebih terampil dan paham mengenai media sosial sehingga lebih bijak dalam penggunaan media sosial. Kegiatan ini diharapkan juga dapat membuat kelompok mitra memiliki pemahaman yang kuat tentang digitalisasi, komunikasi massa, internet dan potensinya dalam proses kehidupan bermasyarakat. Pendidikan bijak media sosial ini diharapkan juga akan menghindarkan konflik horizontal di masyarakat karena perbedaan pendapat utamanya terkait pilihan politik dan isu-isu sensitif lainnya.

\section{METODE PELAKSANAAN}

Pengabdian Kepada Masyarakat Pendidikan Bijak Media Sosial di Kelurahan Tanjung Anom, Kecamatan Pancur Batu, Kabupaten Deli Serdang, Sumatera Utara dilakukan dengan beberapa metode untuk mendukung kinerja pengabdian masyarakat. Terdapat beberapa metode yang dilakukan dalam pelaksanaan kegiatan pengabdian ini, yaitu:

1. Berkoordinasi dengan ketua mitra komunitas Milenial Bijak berkaitan dengan jumlah anggota komunitas dan waktu pelaksanaan sosialisasi. Pertemuan ini bertujuan untuk mengurus izin dalam menjalankan program dan membangun komunikasi yang positif dengan ketua mitra.

2. Melakukan sosialisasi awal terkait kegiatan pendidikan bijak media sosial yang akan dilakukan dalam bentuk pembekalan materi. Saat melakukan proses sosialisasi, semua hal yang ingin dicapai dalam program ini telah dijelaskan secara komprehensif kepada anggota komunitas. Hal ini dilakukan agar selama program berlangsung tidak terjadi kesalahpahaman di antara pihak terkait.

3. Membuat persiapan secara keilmuan dengan menyusun materi-materi pokok (Modul) yang berkaitan dengan materi pembekalan melalui analisis empirik perkembangan media sosial, varian fitur media sosial, fungsi media soal dan beberapa masalah yang muncul dalam penggunaan media sosial.

4. Pembekalan tentang bijak media sosial di komunitas Milenial Bijak di Kelurahan Tanjung Anom. Hal-hal yang disampaikan dalam tahapan ini meliputi orientasi media sosial, pembelajaran bijak media sosial, hingga tujuan utama yang ingin dicapai yaitu pemuda Tanjung Anom agar bijak menggunakan media sosial. Pada tahapan ini juga telah disepakati bahwa media sosial menjadi objek yang akan dikembangkan dan perlu bijak dalam menghadapinya.

5. Melakukan pantauan berkelanjutan dan evaluasi terkait pemahaman anggota komunitas dan implementasi materi yang sudah diperoleh saat pembekalan dilakukan.

\section{HASIL DAN PEMBAHASAN}

\subsection{Pemuda yang Bijak Menggunakan Media Sosial}

Tujuan awal pelaksanaan pendidikan bijak media sosial ini adalah kelompok mitra paham mengenai manfaat dan dampak penggunaan media sosial sehingga lebih bijak dalam penggunaannya.

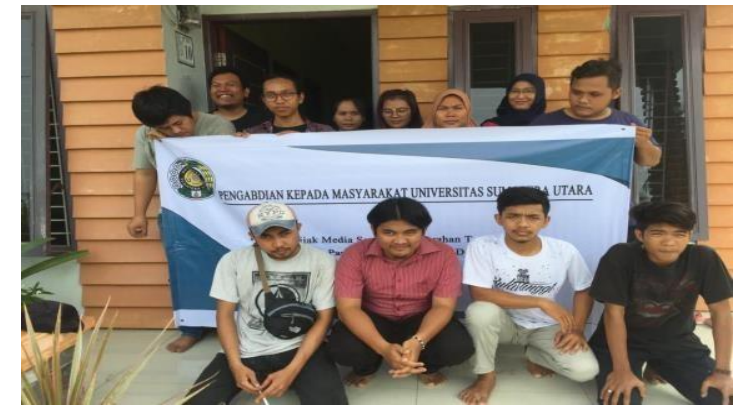

Gambar 10. Foto bersama dengan sebagian peserta sebelum kegiatan dimulai 
Pengabdian masyarakat dalam wujud pendidikan bijak media sosial di era digital ini diharapkan mampu memberikan pengetahuan tentang dampak baik dan buruk penggunaan media sosial.

Dalam skala yang lebih luas, di tengah era digitalisasi yang dampak buruknya seperti yang ada dalam UU No 19 Tahun 2016 tentang Informasi dan Transaksi Elektronik (UU ITE), sedangkan dalam skala yang sempit dapat menghindarkan dan menjauhkan masyarakat di Kelurahan Tanjung Anom dari potensi pidana yaitu pelecehan, penistaan dan perbuatan tidak menyenangkan.

\section{Semua Peserta Bijak Mengoperasikan Media Sosial}

Pengabdian kepada masyarakat bijak media sosial menghasilkan kemampuan dalam memaksimalkan pemanfaatan media sosial berkaitan dengan perannya mempublikasikan informasi dan aktivitas keseharian mereka secara bijak, sehingga mampu untuk mendongkrak citra anak-anak muda di Kelurahan Tanjung Anom. Informasi yang disebarkan juga diharapkan menjadi salah satu rujukan orang tua memantau apa saja yang mereka kerjakan.

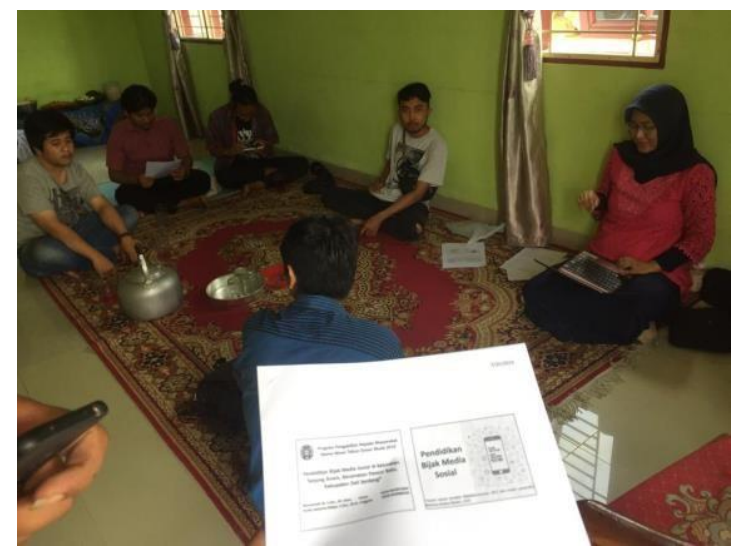

Gambar 8. Kegiatan Pembekalan Materi Pendidikan Bijak Media Sosial

Salah satu contoh yang salah satu peserta yang mempunyai usaha pengadaan daun pisang sebagai alas makanan memutuskan untuk fokus menggunakan akun media sosialnya sebagai salah satu promosi usaha yang sudah ditekuninya selama satu tahun terakhir ini.

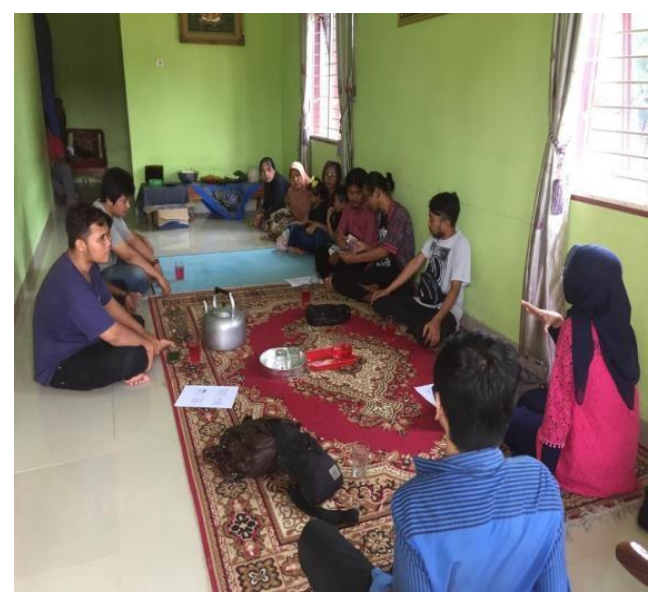

Gambar 9. Pertemuan dengan kelompok Mitra 
Harapannya dengan melakukan promosi melalui media sosial, usahanya dapat lebih luas menjangkau konsumen, Hasil dari kegiatan ini menunjukkan $90 \%$ atau sekitar 18 orang mampu mengoperasikan media sosial sebagai sarana publikasi karena peserta mempunyai lebih dari satu akun media sosial (Facebook dan Instagram). Kemampuan peserta pembekalan juga diukur dengan melakukan quiz secara lisan sebelum kegiatan di mulai dan sesudah kegiatan selesai dilakukan.

\section{Kelompok Mitra Yang Kritis}

Kelompok mitra Pengabdian kepada masyarakat di Kelurahan Tanjung Anom Kabupaten Deli Serdang dibekali berupa penyampaian materi atau sosialisasi mengenai literasi informasi dan pemanfaatan media sosial secara etis, efisien, cerdas dan bijak. Materi yang Pengabdian kepada masyarakat di Kelurahan Tanjung Anom Kabupaten Deli Serdang disampaikan berupa bagaimana literasi informasi diperoleh melalui internet.

Sebagian besar peserta masih sering memanfaatkan media sosial untuk berinteraksi, menyebar berita yang mereka dapat melalui broadcast dan aktivitas lain. Banyak di antara mereka yang secara tidak sadar mengirimkan berita palsu (hoax) yang ada di media sosial.

Melalui kegiatan pembekalan ini, para peserta anak muda Kelurahan Tanjung Anom diminta untuk mampu menahan diri untuk tidak membagi berita yang belum jelas sumbernya dengan memanfaatkan perangkat lunak seperti google image untuk mengecek keabsahan dan kredibiltas penyebar berita atau mengakses situs-situs resmi untuk memeriksa informasi yang beredar di dunia maya.

80\% Peserta atau sekitar 16 orang mampu memanfaatkan fitur google image dalam mengecek kebenaran sumber berita, terutama berita yang berkaitan dengan gambar dan juga mencari informasi melalui web cekfakta.com maupun portal kominfo.go.id. Kegiatan pembekalan ini telah dipublikasikan dalam artikel berita online qureta.com pada bulan Agustus 2019. Selanjutnya tim pengabdian sedang fokus menyelesaikan video dokumentasi kegiatan yang diharapkan dapat diunggah melalui akun Youtube tim pengabdian ataupun melalui akun Youtube milik USUMedia pada akhir Agustus 2019.

Tim pengabdian juga sedang merampungkan artikel yang diharapkan dapat dipublikasikan dalam jurnal nasional Abdimas Talenta USU dan dapat diikutsertakan dalam kegiatan seminar nasional "Hasil Pengabdian Kepada Masyarakat VI yang diselenggarakna pada tanggal 13 November 2019 di Fakultas Pertanian USU.

Rencana berikutnya dari pelaksanaan pengabdian masyarakat ini ialah dengan melakukan monitoring secara berkala melalui kelompok mitra untuk mengetahui perkembangan peserta dalam memanfaatkan materi pembekalan yang diberikan oleh tim pengabdian.

Kegiatan monitoring ini dilakukan dengan memanfaatkan media sosial Facebook dan aplikasi pesan singkat Whatsapp yang digunakan oleh semua peserta. Diharapkan dengan monitoring melalui kedua aplikasi ini kedua pihak secara bersama-sama menjaga komitmen untuk menjadi pemutus mata rantai penyebaran berita palsu (hoax) yang di mulai dari lingkungan terdekat.

\section{KESIMPULAN}

Kegiatan Pengabdian kepada Masyarakat yang dilakukan memiliki dampak yang positif terhadap masyarakat di era arus informasi digital ini. Penggunaan media sosial semakin pesat ditandai dengan semakin banyak media sosial baru bermunculan dan kemudahan akses internet yang dapat dilakukan dengan menggunakan perangkat teknologi yang bermacammacam selama 24 jam nonstop.

Seiring dengan semakin mudahnya mengakses internet, melalui media sosial para pengguna internet di Kelurahan Tanjung Anom, Kabupaten Deli Serdang berbagi informasi mengenai berbagai isu baik ekonomi, sosial dan politik. Kemudahan akses internet ini juga menciptakan 
intensitas berinteraksi yang cukup tinggi antara pengguna media sosial berkaitan dengan berita palsu (hoax) yang beredar dan menciptakan kebiasaan untuk berdiskusi di kalangan komunitas Milenial Bijak di Kelurahan Sindar Raya untuk menghindari perdebatan destruktif.

\section{UCAPAN TERIMAKASIH}

Artikel ini adalah hasil dari Program Pengabdian kepada Masyakarat yang dibiayai oleh BPPTN Universitas Sumatera Utara, sesuai dengan Surat Perjanjian Penugasan Pelaksanaan Pengabdian kepada Masyarakat Program Mono Tahun Dosen Muda, nomor: 331/UN5.2.3.2.1/PPM/2019, tanggal 20 Mei 2019. Tim Pengabdian mengucapkan terima kasih kepada Rektor dan LPPM USU atas dukungan dana dan fasilitas yang diberikan,

\section{DAFTAR PUSTAKA}

Data Asosiasi Penyelenggara Jaringan Internet Indonesia (APJI) Oktober tahun 2018.

Davison P. (2012). The language of Internet Memes. In M Mandiberg (Ed), The Social Media Reader, New York: New York University Press.

Friedman, Thomas L. (2007). The World Is Flat: Sejarah Singkat Abad ke-21. Cet. I. Jakarta: Dian Rakyat.

Gilardi, Fabrizio. (2009). Digital Democracy How Digital Technology Is Changing Democracy and Its Study, UZH Department of Political Science.

Nasrulllah, Rulli. (2017). Media Sosial: Perspektif Komunikasi, Budaya dan Kotemporer. Bandung: PT Remaja Rosdakarya. 